\title{
Pigmented squamous cell carcinoma: case report and importance of differential diagnosis*
}

\author{
Patrícia Motta de Morais ${ }^{1}$ \\ Jeanine Alvarenga Rocha ${ }^{2}$
}

\author{
Antônio Pedro Mendes Schettini ${ }^{1}$ \\ Renato Cândido da Silva Júnior ${ }^{3}$
}

DOI: http:/ / dx.doi.org/10.1590/abd1806-4841.20186757

\begin{abstract}
A few cases of pigmented squamous cell carcinoma affecting the skin and the ocular and oral mucosa of the elderly have been described in the literature. The disease manifests itself as papular and nodular erythematous or pigmented lesions. The main clinical differential diagnoses are pigmented basal cell carcinoma and melanoma. Histopathological examination is characterized by proliferation of atypical squamous cells with formation of horn pearls permeated by dendritic melanocytes. For this reason, a careful diagnosis is necessary to rule out other tumors that show melanin pigment. Surgical removal is the indicated treatment and the prognosis is similar to the classical squamous cell carcinoma. We report a case of pigmented squamous cell carcinoma with diagnosis confirmed by histological and immunohistochemical examinations.
\end{abstract}

Keywords: Carcinoma, squamous cell; Histology; Melanocytes

\section{INTRODUCTION}

Squamous cell carcinoma (SCC) has several histologic variants, such as clear cell SCC, signet ring SCC, basaloid SCC, desmoplastic SCC, verrucous and pigmented SCC, among others. ${ }^{1}$ These subtypes usually require immunohistochemical confirmation. Pigmented squamous cell carcinoma (PSCC) is described as a rare subtype. A review of the English literature showed a frequency of $0.01-7 \% .{ }^{2}$ Other authors identified a higher prevalence, $7-25 \%$, but this variation is due to the inclusion, in some series, of tumors with only small areas of pigmentation. ${ }^{3}$ In 2009, the first case of PSCC was described in Brazilian literature. ${ }^{4}$

We report a case of pigmented squamous cell carcinoma, emphasizing the difficulty in differential diagnosis with other pigmented tumors.

\section{CASE REPORT}

We report a 75-year-old white male patient with a history of a pigmented lesion with pearly edges of an uncertain evolution time in the right temporal region. Our main clinical hypotheses were pigmented basal cell carcinoma and melanoma. We observed no lymphadenopathy and routine laboratory exams showed no change.
The lesion was excised with a margin of approximately $5 \mathrm{~mm}$. The defect was repaired with a skin graft taken from the right infraclavicular region. The patient attended his last follow-up visit two years after surgery, with no signs of local recurrence or metastases.

Microscopic examination revealed a nodular skin cancer, consisting of epithelioid-looking cells, atypical mitotic figures, and horn pearl formation. Pigmented dendritic cells, without atypia, permeated the neoplastic blocks. Surgical margins were described as tumor free (Figures 1 and 2).

Immunohistochemical analysis revealed expression of cytokeratins (AE1/ AE3) and p40 protein in epithelioid cells and expression of gp100 (HMB45) in pigmented dendritic cells (Figures 3 and 4). Thus, we confirmed the diagnosis of PSCC.

\section{DISCUSSION}

The present case is similar to other cases described in the literature, since we identified the association of the usual histological findings of classical SCC with an increase in pigmented dendritic melanocytes in the parenchyma and melanophages in the stroma, making the differential diagnosis with melanocytic neoplasias diffi-

\footnotetext{
Received on 11.12.2016.

Approved by the Advisory Board and accepted for publication on 24.04.2017.

Work performed at Fundação Alfredo da Matta (Fuam) - Manaus (AM), Brazil.

Financial support: none.

Conflict of interest: none.

Division of Histopathology at Fundação Alfredo da Matta (FUAM) - Manaus (AM), Brazil.

Private clinic - Botucatu (SP), Brazil.

Division of Surgery at Fundação Alfredo da Matta (FUAM) - Manaus (AM), Brazil.
}

MAILING ADDRESS:

Patrícia Motta de Morais

E-mail: pattymmorais@hotmail.com

C2018 by Anais Brasileiros de Dermatologia 


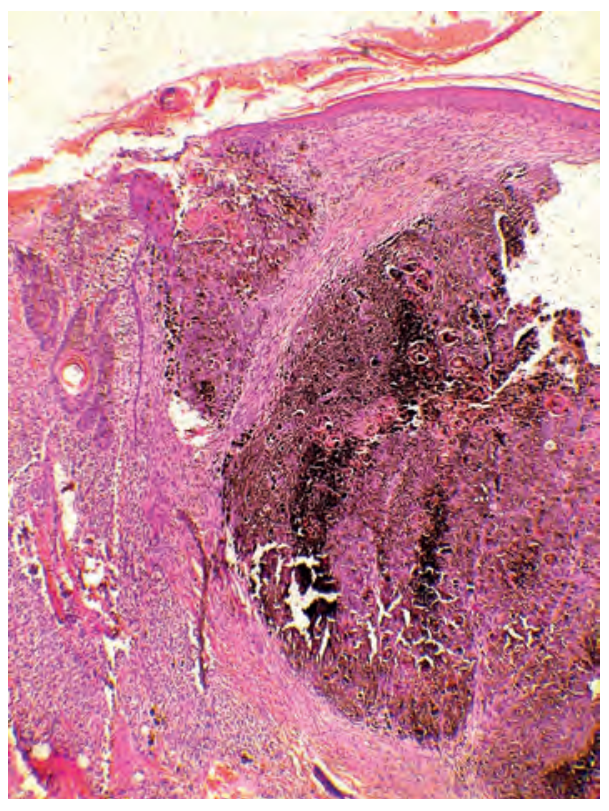

Figure 1: Lobular dermal neoplasm of epidermal origin with abundant melanin pigment (Hematoxylin \& eosin, $\mathrm{X} 40)$

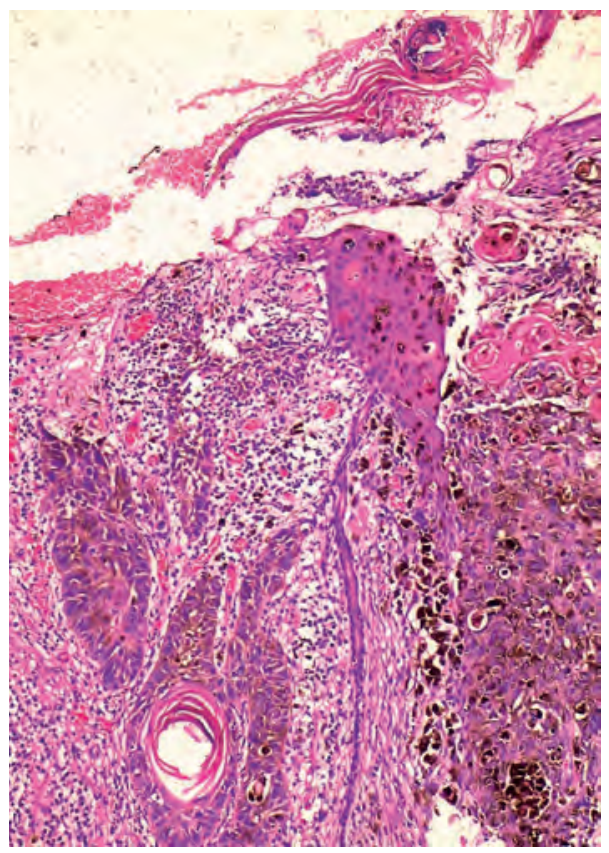

Figure 2: Detail of the squamous differentiation of the neoplastic cells and the interspaced pigmented melanocytes (Hematoxylin \& eosin, X100)

cult to rule out. The final diagnosis was confirmed by the immunohistochemical examination that revealed tumor cells infiltrated by melanocytes, with the expression of epidermal squamous cells and melanocytes.

The association of epithelial cells and melanocytes is usually found on skin, on skin appendages, and in a large number of malignant or benign tumors, which may cause difficulties in the differential diagnosis with melanoma. ${ }^{5}$

Several terms are used to describe tumors composed of different neoplastic cell types in the same lesion.

Satter et al. (2009), ${ }^{6}$ in a literature review, classified these tumors into four categories: a) collision tumors: two independent neoplasms that occur close to each other but tumor cells do not

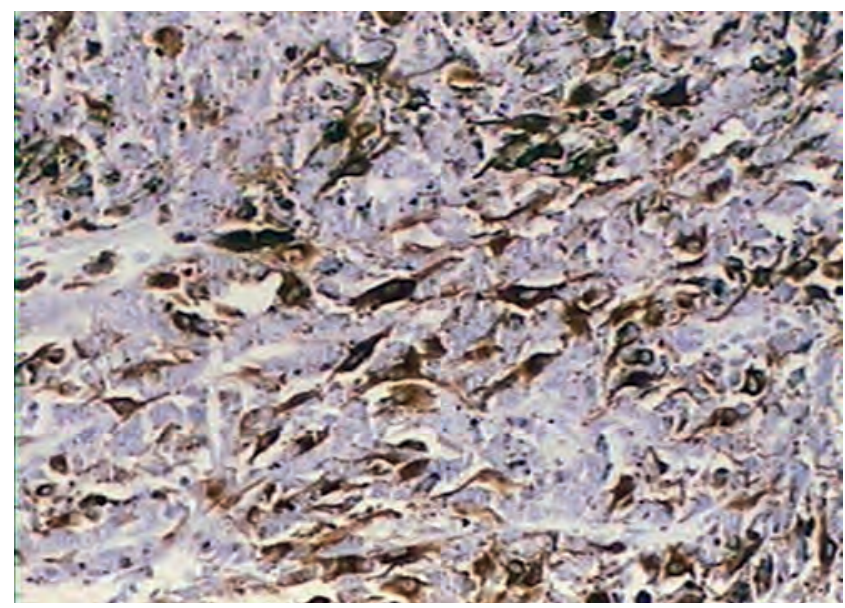

Figure 3: Immunohistochemistry: expression of melan-A (Mart1) in melanocytes

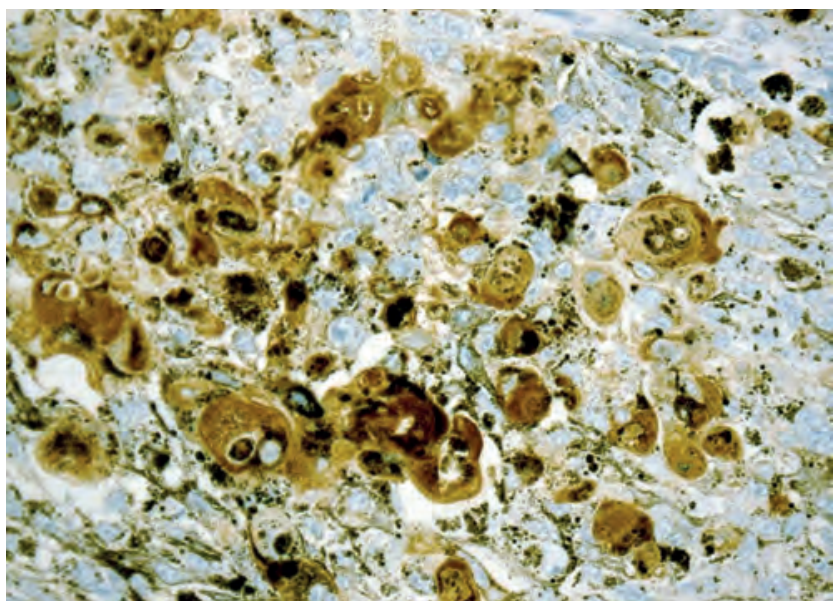

FIGURE 4: Immunohistochemistry: expression of cytokeratins (AE1/AE3)

mix; b) combined tumors: composed of two distinct neoplasms of malignant cells that fuse imperceptibly and are better discerned by immunohistochemical study; ${ }^{7} \mathrm{c}$ ) biphenotypic tumors: these tumors coexpress immunohistochemical markers and have the same molecular properties in both cell components of the tumor. They appear to arise from a common stem-cell precursor that undergoes divergent differentiation; ${ }^{6,89} \mathrm{~d}$ ) colonized tumors: a tumor cell population that permeates and colonizes another pre-existing neoplasia. In the original description, an in situ melanoma colonized a basal cell carcinoma. This term is mainly used to refer to benign and malignant epithelial neoplasms that are populated by dendritic melanocytes without atypia, such as pigmented actinic keratosis, pigmented Bowen's disease, pigmented basal cell carcinoma, melanoacanthoma, and pilomatricoma. ${ }^{2,9-11}$ PSCC seems to be part of this last category. The mechanism of melanocytic colonization in tumor masses is unknown. An hypothesis is that melanocytes derive from pluripotential stem cells in the hair matrix or even from neural crest cells. ${ }^{5}$

The main histological differential diagnoses of PSCC are:

Pigmented seborrheic keratosis (PSK): it has the same characteristics of seborrheic keratosis, but with increased melanin pig- 
ment in keratinocytes. ${ }^{12,13}$

Melanoacanthoma: some authors suggest that it is a subtype of PSK. It differs from PSCC by the increased number of pigmented dendritic melanocytes among keratinocytes. ${ }^{12,14}$

Pigmented pilomatricoma: benign dermal or subcutaneous tumor derived from the hair matrix, characterized by aggregates of (matrix or supra-matricial) basaloid cells and filled centrally with masses of eosinophilic cornified material containing shadow cells, sometimes revealing calcification, and even ossification within the lesion. The pigmented variant is characterized by the presence of pigmented dendritic melanocytes within the neoplastic cells, and melanin pigment within the basaloid cells and shadow cells. ${ }^{15}$

Pigmented actinic keratosis: characterized by hypertrophic dendritic melanocytes containing incorporated melanosomes. The melanin pigment is evidenced by dysplastic keratinocytes and dermal macrophages. ${ }^{12}$

Pigmented Bowen's disease: Bowen's disease corresponds to the in situ variant of SCC. The pigmented form is characterized by the retention of melanin pigment in the cytoplasm of atypical keratinocytes, as well as an increased number of dendritic melanocytes without atypia with pigmented melanosomes. Two cases of pigmented Bowen's disease have been studied from a dermoscopic perspective. Features such as honeycomb-like circles, peripheral streak-like projections, brown spots, and scales were found. ${ }^{16,17}$
Pigmented basal cell carcinoma: basal cells are derived from germ cells with scarce cytoplasm and large nuclei and form a palisade in the periphery of the tumor blocks involved by collagen retraction artifact. ${ }^{12}$ Dendritic melanocytes without atypia are distributed throughout tumor nests, and melanophages are present in the stroma. ${ }^{18,19}$

Squamo-melanocytic tumor: to date, 17 cases of squamo-melanocytic tumors have been reported in English literature. The most common sites appear to be the head and neck, followed by the extremities. ${ }^{6,20} \mathrm{~A}$ case in the plantar region has been recently described. It differs from PSCC because it consists of two distinct malignant cellular components (epithelial and melanocytic components). Therefore, it is classified as a combined tumor. ${ }^{8}$

Melanoma (especially the verrucous variant or cases associated with pseudoepitheliomatous hyperplasia): the epidermal component is reactive and benign, and the melanocytic component is malignant. ${ }^{12}$

The present case approaches the difficulty in differentiating PSCC from other melanocytic neoplasias, especially melanoma. Several authors have studied its pathogenesis, trying to identify its singularities in relation to biological and therapeutic evolution. Although the number of published cases is reduced to a consensus, it seems that PSCCs evolve and have a similar therapeutic response to classical SCCs, corroborating the misdiagnosis of SCC colonized by benign melanocytes. $\square$

\section{REFERENCES}

1. Weedon D, Morgan MB, Gross C, Nagore E, Yu LL. Acantholytic squamous all carcinoma. In: LeBoit PE, Burg G, Weedon D, Sarasin A, editores. Pathology and genetics. Albany: W.H.O. Publication Center; 2006. p. 20-25.

2. Satter EK. Pigmented squamous cell carcinoma. Am J Dermatopathol. 2007;29:486-9.

3. Carrasco L, Fortes J, Sarasa JL, Moreno MC, Izquierdo MJ, Saez MA et al. Carcinoma espinocelular cutáneo pigmentado: descripción de dos casos. Actas Dermosifiliogr. 2000;91:39-42.

4. Jeunon T, Vita-Campos CM, Azeredo-Coutinho RB. Caso para diagnóstico. Carcinoma de células escamosas pigmentado da pele. An Bras Dermatol. 2009;84:293-5.

5. Jurado I, Saez A, Luelmo J, Diaz J, Mendez I, Rey M. Pigmented squamous cell carcinoma of the skin: report of two cases and review of the literature. Am J Dermatopathol. 1998;20:578-81.

6. Satter EK, Metcalf J, Lountzis N, Elston DM. Tumors composed of malignant epithelial and melanocytic populations: a case series and review of the literature. J Cutan Pathol. 2009;36:211-9.

7. Braun-Falco M. Combined malignant melanoma and basal cell carcinoma tumor of the intermingled type. J Cutan Pathol. 2007;34:731-5.

8. Malhotra KP, Shukla S, Husain N, Bhatt ML. Combined squamomelanocytic tumor of the plantar surface of the foot: histogenetic Insights. Am J Dermatopathol. 2016;38:396-7.

9. Cornejo KM, Deng AC. Malignant melanoma within squamous cell carcinoma and basal cell carcinoma: is it a combined or colision tumor ? - a case report and review of the literature. Am J Dermatopathol. 2013;35:226-34.

10. Florell SR, Zone JJ, Gerwels JW.. Basal cell carcinomas are populated by melanocytes and Langerhan's cells. Am J Dermatopathol. 2001;23:24-8.

11. Schubert B, Rudolph P. Basal cell carcinoma: a natural milieu for melanocytes? Am J Dermatopathol. 2001;23:558-60.
12. Morgan MB, Lima-Maribona J, Miller RA, Kilpatrick T, Tannenbaum M. Pigmented squamous cell carcinoma of the skin: morphologic and immunohistochemical study of five cases. J Cutan Pathol. 2000;27:381-6.

13. Kossard S, Epstein Jr EH, Cerio R, Yu LL, Weedon. Keratinocytic tumours. In: D LeBoit PE, Burg G, Weedon D, Sarasin A. Pathology and genetics: classification of tumours. Geneva: WHO; 2006. p. 42.

14. Kossard S, Epstein Jr EH, Cerio R, Yu LL, Weedon. Keratinocytic tumours. In: D LeBoit PE, Burg G, Weedon D, Sarasin A. Pathology and genetics: classification of tumours. Geneva: WHO; 2006. p. 43.

15. Ishida M, Okabe H. Pigmented pilomatricoma: an underrecognized variant. Int J Clin Exp Pathol. 2013;6:1890-3.

16. Fraga-Braghiroli N, Stephens A, Oliviero M, Rabinovitz H, Scope A. Small brown circles: an importante diagnostic clue for pigmented squamous cell carcinoma. J Am Acad Dermatol. 2013;69:e161-3.

17. Chung E, Marchetti MA, Pulitzer MP, Marghoob AA. Streaks in pigmented squamous cell carcinoma in situ. J Am Acad Dermatol. 2015;72:S64-5.

18. Kossard S, Epstein Jr EH, Cerio R, Yu LL, Weedon. Keratinocytic tumours. In: D LeBoit PE, Burg G, Weedon D, Sarasin A. Pathology and genetics: classification of tumours. Geneva: WHO; 2006. p. 19.

19. Calonje E, Brenn AL, McKee PH. McKee's pathology of the skin. 4th ed. Philadelphia: Elsevier Saunders; 2012.

20. Cornejo KM, Deng AC. Malignant melanoma within squamous cell carcinoma and basal cell carcinoma: is it a combined or collision tumor?: a case report and review of the literature. Am J Dermatopathol. 2013;35:226-34.

How to cite this article: Morais PM, Schettini APM, Rocha JA, Silva Junior RC. Pigmented squamous cell carcinoma: case report and importance of differential diagnosis. An Bras Dermatol. 2018;93(1):96-8. 